\title{
Vironkielisen tekstin ymmärtäminen suomen kielen pohjalta
}

\author{
PIRKKO MUIKKU-WERNER \\ Itä-Suomen yliopisto
}

Tiivistelmä. Lähtö- ja kohdekielen samankaltaisuuden vaikutusta oppimiseen on paljon tutkittu. Lisätietoa kaivataan kuitenkin siitä, miten vastaavuuksista hyödytään ilman systemaattista opetusta. Esimerkiksi virolaisten ja suomalaisten keskinäisissä arkikeskusteluissa kunkin osallistujan on mahdollista käyttää omaa äidinkieltään, josta toinen onnistuu poimimaan yhteisiä elementtejä. Tällainen reseptiivinen monikielisyys kytkeytyy myös tekstien maailmaan: sukukielten toisiaan muistuttavien sanojen tiedetään auttavan luetun ymmärtämistä. Artikkelissa on tarkoitus selvittää, mitä sanoja suomalainen tunnistaa koherentista vironkielisestä tekstistä, onko samankaltaisuus ratkaisevassa asemassa vai tarjoutuuko muitakin selityksiä. Käännöstestin tuloksista tehtyjen havaintojen tukena ovat informanttien omat kuvaukset ymmärtämisen edellytyksistä.

Odotuksenmukaisesti helpoimmin löydetään merkitykset kirjoitusasultaan likeisille vastineille, joita haetaan paitsi nykykielestä myös vanhahtavista sanoista tai yhteisistä lainasanoista. Aina edes samankaltaisuus ei riitä, jos koteksti ei tue tutuksi toteamista. Kiinnostavaa on se, että mikäli tekstistä kyetään rakentamaan yhtenäinen ja mielekäs - ei välttämättä kirjoittajan tarkoittama - jakso, jopa ilmiselvältä vaikuttava sukulaissana poistetaan tai käännetään 'väärin'. Tuloksia arvioitaessa on siis muistettava 'maallikkokääntäjän' erilaiset, joko sanasta sanaan etenevät tai kokonaisuutta rakentavat käännösstrategiat.

Avainsanat: lähisukukieli; reseptiivinen monikielisyys; samankaltaisuus; käännöstesti 


\section{Kielisukulaisuus, monikielisyys ja ymmärtäminen}

Suomalaisten ja virolaisten vuorovaikutuksessa on varsin tavallista, että kukin osallistuja käyttää vähintään osittain äidinkieltään, mikä edellyttää toisen puhujan kielen ymmärtämistä (ns. reseptiivisestä monikielisyydestä ks. esim. Braunmüller 2007 ja Zeevaert \& ten Thije 2007). Ensikosketus lähisukukieleen liittyykin useimmiten puhetilanteisiin, mutta Virossa viipyvä ei voi kuitenkaan välttää törmäämistä kyltteihin, ohjeisiin, tuoteselosteisiin, tietoiskuihin tai lehtiotsikoihin. Erityisesti maahan muuttava joutuu tekemisiin kirjallisten dokumenttien kanssa lomakkeista lehtiartikkeleihin, kirjeistä tutkielmiin. Kohdattujen viestien maailma on multimodaalinen. (Dufva ym. 2011: 116.) Perehtyminen teksteihin on kenelle tahansa tärkeää siksi, että esimerkiksi opasteen ymmärtäminen voi säästää aikaa tai käyttöohjeen ymmärtäminen vaivaa, jopa rahaa. Tutkiessaan virolaisten ja suomalaisten monikielistä viestintää Anna Verschik (2011: 267) on havainnut, että suullisessa vuorovaikutuksessa suomalaiset käyttävät hyväkseen käsillä olevia vironkielisiä resursseja ja siteeraavat vironkielisiä tuoteselosteita ja etikettejä. Ihannetilanne olisi tietysti se, että he olisivat selvillä siitä, mitä niissä sanotaan.

Viron ja suomen välistä reseptiivistä monikielisyyttä on toistaiseksi tutkittu varsin niukasti. Kuitenkin vanhemmille suomalaisille jopa viron sanaston vähäisestä ymmärtämisestä on hyötyä, sillä he eivät välttämättä ymmärrä kansainvälisiin kohtaamisiin tarjoutuvaa, yhteiseksi kieleksi (lingua franca) oletettua englantia. Viestien sisällön selvittämisessä suomea muistuttavien elementtien havaitsemisella on tietysti keskeinen asema. Melko vähän on tietoa siitä, miten lähisukukielten yhtäläisyyksiä hyödynnetään pyrittäessä ymmärtämään viroa tai suomea niissä tapauksissa, jolloin kyseistä kieltä ei ole lainkaan opetettu tai siitä ei ole kuin joitakin epäjärjestelmällisiä havaintoja. REMU-verkostossa ${ }^{1}$ toteutettu

\footnotetext{
1 REMU-verkostoon (Reseptiivinen monikielisyys: viron ja suomen keskinäinen ymmärrettävyys) kuuluu tutkijoita Itä-Suomen, Tallinnan, Jyväskylän ja Helsingin yliopistoista sekä Åbo Akademista.
} 
pilottitutkimus on keskittynyt sanojen ymmärtämiseen ensiksi ilman tekstiyhteyttä, toiseksi irrallisissa lauseissa ja kolmanneksi koherentissa tekstissä. Kahteen ensimmäisen teemaan keskittyvistä tutkimuksista on raportoitu Lähivertailuja 22:ssa (Muikku-Werner \& Heinonen 2012; Paajanen \& Muikku-Werner 2012). Tässä artikkelissa perehdytään siihen, miten yhtenäinen teksti vaikuttaa ymmärtämiseen. Näiden kolmen kokeellisen osatutkimuksen avulla on haluttu testata muun muassa metodisten ratkaisujen toimivuutta ja käännettävien sanojen valinnan onnistuneisuutta.

Kaiken kaikkiaan reseptiivisen monikielisyyden nykytutkimus toisin kuin aiempi - ei enää fokusoidu pelkästään läheiseen kielisukulaisuuteen. Keskinäistä ymmärrettävyyttä ei pidetä kielten luontaisena ominaisuutena, vaan sen katsotaan olennaisesti kuuluvan monikieliseen kommunikaatioon dynaamisena prosessina (Rehbein ym. 2011: 253). Monikielisissä tilanteissa ei tarvitse edellyttää kielten välistä geneettistä läheisyyttä, vaan ymmärtämisprosesseissa voidaan turvautua esimerkiksi keskeisenä pidettyyn päättelyyn, jonka katsotaan perustuvan paitsi lingvistiseen myös maailmantietoon (Singer 2007: 343).

Reseptiivisen monikielisyyden rinnalla voitaisiinkin puhua yleisemmin lingua receptivasta $(\mathrm{LaRa})$. Sillä tarkoitetaan niiden lingvististen, mentaalisten, interaktiivisten ja kulttuurienvälisten kompetenssien kokonaisuutta, jotka aktivoituvat, kun kuulija passiivisella kielellään tai varieteetillaan havainnoi puhujan lingvististä toimintaa tai puhuja koettaa kontrolloida ymmärtämisprosessia tarkkailtuaan kuulijan tapaa aktivoida passiivista tietoaan. Suullisessa interaktiossa ymmärtämistä edistäviin kielellisiin keinoihin sisältyy muun muassa nonverbaalisia signaaleja, mielipidettä ilmaisevia prosodisia elementtejä, sanoman perillemenon estymisen toteamista ja kaikukysymyksiä. Sanaston tasolla puhuja mukauttaa lausumiaan sen perusteella, mitä olettaa kuulijan ymmärtävän. Lisäksi LaRa turvautuu intensiivisesti päättelyyn. (Rehbein ym. 2011: 249, 254.)

Edellä sanottua on mahdollista soveltaa myös kirjoitetun kielen maailmaan. Luettaessa tekstejä kielellä, jota ei ole opiskeltu, dekoo- 
daaminen vaatii monenlaisia kykyjä. Kirjoittajahan - toisin kuin puhuja suullisessa interaktiossa - ei välttämättä pyri helppolukuiseen viestintään, joten lukijat joutuvat merkittävästi tehostamaan erilaisia kompetenssejaan. Heidän onkin todettu hyödyntävän täydentäviä segmentoinnin keinoja, sukukielisyydestä johdettua morfologista ja syntaktista metatietoa sekä toisiinsa yhteydessä olevien rakenteiden syntaktisia ja semanttisia jäsennyksiä. (Rehbein ym. 2011: 250.) Apuna on tieto kaikista prosessoinnin tasoista: skripteistä, oikeinkirjoituksesta ja sanoista käyttösääntöineen (Lutjeharms 2007: 276). Myös tekstityypeistä ja -malleista sekä tekstin funktioista on tarpeen olla perillä, koska ne synnyttävät odotuksia tekstin tavoitteesta ja sisällöstä. Lisäksi ymmärtämiseen eittämättä vaikuttavaa samankaltaisuutta on syytä tarkastella moniulotteisesti: ratkaistaanko likeisyys vertaamalla ilmausta standardikielen leksikkoon, vai ovatko rinnastuksen lähteinä kaikki varieteetit? Vuorovaikutustilanteessa valinnat eivät ole itsestään selviä, ja sama pätee tekstien yhteydessä: vaikka lähtökohtana on useimmiten yleiskieli, lukijalla on resurssinaan muitakin vaihtoehtoja. Ymmärtäjinä ovat lukijat eivätkä kielen systeemit. (Rehbein 2006; Verschik 2011: 270.)

Kaivapalu ja Muikku-Werner (2010: 84) ovat jo aiemmin osoittaneet strategisen kompetenssin, maailmantiedon sekä tunnistamisen tukena olevien monenlaisten lingvististen repertuaarien tärkeyden viron ymmärtämisessä. Erityisesti maailmantiedolla on keskeinen osa. Varhemman kokemuksen pohjalta luodaan oletusarvoja ja abstraktioita; aiheesta tarjolla oleva kehystyyppinen informaatio helpottaa asioiden sekä niiden välisten yhteyksien hahmottamista. Näin potentiaaliset tietoaukot ovat ehkä korjattavissa, jolloin tekstistä on mahdollista tehdä koherentti. (Lutjeharms 2007: 277.) Käytännön tilanteissa kaikkien sanojen merkityksen tunteminen ei ole välttämätöntä, mutta järjellisen kokonaisuuden luomiseksi tarvitaan päättelyä ja tietyntyyppistä karsintaa. Sinänsä loogisen tekstin syntymistä eivät tosin väärinkään tulkitut sanat estä, kun kirjoitus rakennetaan omien, ei alkuperäiskirjoittajan mielikuvien pohjalta (ks. myös s. 227). 
Ymmärrettävyyteen on havaittu vaikuttavan myös ekstralingvististen muuttujien, kuten asenteiden, maantieteellisen etäisyyden, kohdekielisen inputin saatavuuden ja kontaktien määrän. Esimerkiksi myönteisten asenteiden ei kuitenkaan ole voitu osoittaa parantavan testistä suoriutumista. (Van Bezooijen \& Gooskens 2007: 249-254.) Oletan, että suomalaisten kesken ei viroa koskevissa asenteissa ole niin suuria eroja, että sitä kannattaisi tässä käsitellä. Testattavat on kuitenkin valittu niin, ettei heillä ole ollut kokemusta viron kielestä lainkaan tai kosketus siihen on ollut lyhytkestoista, turistimatkojen mittaista. Kontaktien määrää voi pitää melko vakioisena, mutta niiden myönteisyydestä tai kielteisyydestä ei ole tietoa.

Kirjoitetun kielen ymmärtämiseen on toki kiinnitetty huomiota aiemminkin, ja sitä voidaan kontrolloida eri tavoin. Testattaessa viestin välittymistä monikielisessä tilanteessa on havaittu, että käytetty metodi vaikuttaa suuresti tuloksiin. Delsing (2007: 235) on verrannut toisiinsa erilaisia menetelmiä selvittäessään skandinaavisten kielten keskinäistä ymmärrettävyyttä. Hänen arvioimiaan testityyppejä olivat 1) avoimet kysymykset, 2) oikein-väärin-kysymykset, 3) monivalintakysymykset), 4) sanakäännökset, 5) tiivistelmät (sai kirjoittaa niin paljon kuin halusi) ja 6) lyhyet tiivistelmät. Kaikkein parhaiten menestyttiin oikein-väärin-kysymyksissä, sitten monivalintatehtävässä, avoimissa kysymyksissä, sanakäännöksissä ja tiivistelmässä, huonoiten lyhyissä tiivistelmissä. Mahdollisuus päätyä oikeaan vastaukseen oikein-väärinja monivalinta-kysymysten yhteydessä on automaattisesti suuri. Vastatessaan valmiiksi muotoiltuihin kysymyksiin testattava voi tukeutua sekä tekstiin että tarjottuihin vaihtoehtoihin. Avoimissa kysymyksissä tai tiivistelmässä taas tiedot tekstin aihepiiristä voivat auttaa. (Doetjes 2007: 224-226.) Seuraavassa luvussa esittelen omaa lähestymistapaani ja perustelen sen valintaa tutkimuskysymyksistä ja -aineistosta käsin. 


\section{Tutkimuksen tavoitteet, lähestymistapa ja tutkimusaineisto}

Tämän artikkelin tavoitteena on vastata seuraaviin pääkysymyksiin: 1) millaisia viron sanoja yhtenäisestä tekstistä tunnistetaan, 2) mitkä seikat edistävät kokonaisuuden ymmärtämistä, millaisia aktivoituneita prosesseja on jäljitettävissä, ja 3) kuinka tietoisia ymmärtämisen edellytyksistä ollaan. Aiempien tutkimusten perusteella ei-äidinkielisen tekstin ymmärtämisessä suuri merkitys on samankaltaisuudella (samankaltaisuuden lajeista ks. tarkemmin Ringbom 1987: 130-145 ja 2007: 19-29), joten oletan sen vaikuttavan myös koherentin tekstin merkitystä selvitettäessä.

Edellisessä luvussa esittelin erilaisia sanaston ymmärtämistä testaavia menetelmiä. Omassa tutkimuksessani päädyin tekstin kääntämiseen. Suomen kielen opiskelijoiden tehtävänä oli kääntää noin 45 minuutissa vironkielisestä tekstistä kaikki ymmärtämänsä. Instruktion väljyyden tuottamiin ongelmiin palaan myöhemmin. Myös tekstin haasteellisuuden arviointi osoittautui varsin pulmalliseksi. Terttu Nurron alun perin englanninkielinen kirjoitus Sild üle mere (ks. liite 1) käsittelee virolaissuomalaisia kulttuurisuhteita. Teksti on sisällöllisesti osittain helppo sikäli, että siinä puhutaan muun muassa kielisukulaisuudesta. Näin ollen testattavilla on aiheen tuttuuden kautta mahdollisuus ymmärtää asiakokonaisuuksia. Myös Viron historian tuntemuksesta on apua. Kääntämistehtävän heikkoutena on se, ettei testiin osallistuvien taustatiedon määrää voida kontrolloida. Tuttujen elementtien mukanaolo on kuitenkin välttämätöntä sen vuoksi, että opiskelijoiden motivaatio säilyy. Sitä paitsi muilla menetelmillä, esimerkiksi oikean vastauksen poiminnalla tarjokkaiden joukosta, saadaan liian paljon oikeita vastauksia eikä tiedetä, milloin kyse on arvauksesta. Pelkästään erillisten sukulaissanojen tunnistaminen puolestaan ei olisi tuottanut tietoa siitä, miten ko- ja kontekstia hyödynnetään tekstin ymmärtämisessä. Otsikollisen kirjoituksen voi olettaa olevan koherentti kokonaisuus, johon on mahdollista sisällyttää mukana olevia yksittäisiä asioita loogisten kytköksien kautta. 
Tuloksia arvioitaessa on kuitenkin pidettävä mielessä, että nimenomaan kääntämisen käyttö testauksen välineenä on saattanut vaikuttaa niihin. Jotta opiskelijoiden käyttämät ymmärtämisstrategiat eivät jäisi vain arvailujen varaan, heitä pyydettiin kertomaan niistä.

Tutkimuksen informantteina on yhteensä 22 Itä-Suomen ja Jyväskylän yliopiston suomen kielen opiskelijaa. Testaushetkellä he eivät vielä olleet aloittaneet viron opiskeluaan eikä heillä ole ollut kuin hyvin satunnaisia kontakteja viron kieleen, lähinnä lyhyitä matkoja Viroon. Heillä on kuitenkin aiempien opintojensa perusteella tietoa viron ja suomen sukulaisuudesta. Analysoitavana materiaalina ovat siis opiskelijoiden paikoin yhtenäiset, paikoin katkonaiset käännökset sekä heidän vastauksensa, joissa he punnitsevat ymmärtämisen edellytyksiä ja sen edistämistä auttavia keinoja.

Vaikka artikkelissa keskitytään ennen kaikkea ymmärtämisen onnistumiseen, lyhyesti kannattaa mainita epäonnistumisen mahdollisuudesta. Monikielisessä tilanteessa aktivoituvien kompetenssien runsauden vuoksi väärinymmärrysten syyt eivät ole palautettavissa pelkästään morfosyntaktiselle tai leksikaaliselle tasolle, vaan päättely saattaa harhautua väärille jäljille esimerkiksi hallussa olevan taustatiedon virheellisyyden tai sen puutteen vuoksi. Näin tekstiin tutustuvan ymmärrystä ohjaa se, millaisen sanoman hän uskoo viestijän aikoneen välittää kyseisessä tilanteessa, millainen sisältö olisi jollain tapaa relevantti ja odotuksenmukainen. (Rehbein ym. 2011: 250-252.) Paajanen (2012: 25-28) on osoittanut, että nimenomaan irrallisiin lauseisiin perehtyvä saattaa tuottaa järjellisen mutta virheellisen kokonaisuuden. Oletuksena on, että harhaantuminen on mahdollista myös yhtenäisessä tekstissä, jollainen nyt on tarkasteltavana.

\section{Ymmärtäminen ja siihen vaikuttavat tekijät}

Kielisukulaisuudesta koituva hyöty on pystytty osoittamaan useissa tutkimuksissa (ks. tarkemmin Kaivapalu 2007 ja 2009). Monesti samankaltaisuus on yhdistetty petollisiin ystäviin eli pulmasanoihin, joista 
oppikirjoissa ja sanakirjoissa on aiheellisesti varoiteltu (ks. esim. ks. Kuldsepp \& Seilenthal 1980; Kasik 1994; Alvre \& Vodja 1995; Pajusalu ym. 1999). Niihin ei tässä artikkelissa kajota, koska tavoitteena on ensisijaisesti esitellä onnistuneita ratkaisuja. Ensimmäisessä alaluvussa käsittelenkin informanttien oikein kääntämien sanojen laatua yleisellä tasolla. Toisessa alaluvussa havainnollistan muutaman erillistapauksen avulla ko- ja kontekstin vaikutusta yksittäisen sanan ymmärtämiseen. Tuotos ei aina ole välttämättä virheetön eikä virheellinen, olipa kyseessä oleva leksikaalinen elementti kielisukulaisuuden pohjalta tunnistettavissa tai ei.

\subsection{Oikein käännettyjä sanoja}

Taulukkoon 1 on koottu sanoja, jotka vähintään viisi suomenopiskelijaa on kääntänyt oikein. Kääntämisen onnistumiseen on toki suuresti vaikuttanut tekstiympäristö. Kyse ei ole sanojen ehdottomasta tunnistamisesta tai ymmärtämisen helppoudesta, mikä näkyy jo siitä, että joidenkin kahdessa eri paikassa esiintyvien sanojen, kuten vaid, oikeiden käännösvastineiden määrä vaihtelee. Kun tehtävänannossa kehotettiin suomentamaan kaikki ymmärretty aines eikä esimerkiksi jokainen tiedetty sana, testattava saattaa jättää kääntämättä aika itsestään selvänkin sukukielisen sanan (esim. rahapada), mikäli hän ei ole saanut sitä ympäröivästä tekstijaksosta syntymään kokonaisuutta. Tästä strategiasta johtuu joidenkin sukulaissanojen sijoittuminen ehkä epäodotuksenmukaisesti taulukon loppuun. Näin taulukko ei kerro siitä, mitä sanoja todella ymmärretään, vaan vain listaa ne, jotka on käännetty oikein kulloisessakin tekstiyhteydessä. Koska testattavia ei haastateltu, ei voida varmasti tietää, millaiset seikat ovat ohjanneet heidän valintojaan tai miksi jokin tapaus on vaikea, toinen ei. Luvussa 4 esitetyt yleisluonteiset prosessinkuvaukset antavat kuitenkin jonkin verran tietoa ratkaisujen taustoista, mutta tässä luvussa nojataan pelkkiin käännöksiin.

Informantit tekevät erilaisia ratkaisuja. Kaikki eivät kääntäneet otsikkoa, joten sild, üle ja mere eivät pääse aivan listan kärkeen. Moni 
käyttää rinnakkaisia tapoja ilmaista asioita: soome ja eesti keel korvataan sanaliitolla 'suomi ja eesti', joka on suomessa täysin ekvivalentti vastine, vaikka virossa keel onkin lähes pakollinen aines. Jotkin sanoista, kuten partnerlussuhted, saavat lukuisia vastineita, jotka jollain tapaa sopivat tekstin sisältöön: 'ystävyyssuhde' (3 kpl), 'yhteistyö' (3 kpl), 'yhteistyösuhde,' 'kaveruussuhde' ja 'kumppanuus'. Huomattakoon lisäksi, että pikka aega on esitetty taulukossa sanaliittona, koska se on käännetty suomeksi yhtenä sanana, esim. 'pitkään' tai 'kauan'.

Listattujen oikeiden käännösten määriä arvioitaessa on siis muistettava, että kaikki huomiot perustuvat vain tähän tekstiin: ei voi sanoa, että kyseiset sanat olisi tunnistettu jossain muussa ympäristössä. Valitettavasti tässä yhteydessä ei ole mahdollista käydä läpi jokaisen oikean käännöksen kotekstiä. Myös testattavien yksilölliset erot vaikuttavat tuloksiin. Vaikka joissain tutkimuksissa nostetaan esiin virheellisiä ratkaisuja, olen kuitenkin halunnut toimia päinvastaisesti. Pohdiskelen varsin yleisellä tasolla, onko käännettävän kirjoituksen viron sanoista löydettävissä suomesta poikkeavia piirteitä, jotka eivät näyttäisi haittaavan ymmärtämistä.

TAULUкко 1. Yleisimmät oikein käännetyt sanat

\begin{tabular}{|l|l|}
\hline $\begin{array}{l}\text { Tunnistaminen } \\
\text { (maksimi } \\
\text { 22 kertaa) }\end{array}$ & \multicolumn{1}{c|}{ Sanat } \\
\hline 22 & kolm, tundi, Soome \\
\hline 21 & lisaks, sugulaskeeled (+ lähisukukielet) ${ }^{*}$, informatsiooni \\
\hline 20 & soome, vaheliste \\
\hline 19 & lahte, kahe, kuulub, soomeugri, instituut, kilomeetrit \\
\hline 18 & maa, lähedased, mõlemal \\
\hline 17 & $\begin{array}{l}\text { levitamiseks (+ lisäämiseksi), keelerühma (+ kielisuku, } \\
\text { kielikunta, kieliperhe), vaid }\end{array}$ \\
\hline 16 & toimis \\
\hline 15 & teine, maailmasõda, avatigi, maailmas, üks \\
\hline
\end{tabular}




\begin{tabular}{|c|c|}
\hline 14 & kaarsild, vahel \\
\hline 13 & laevasõitu (+ 7 x laivalla), direktor \\
\hline 12 & $\begin{array}{l}\text { kestnud, pikka aega (+ } 2 \times \text { kauan, } 2 \times \text { pitkään), see, } \\
\text { kultuurisuhtele, nimi, keel }\end{array}$ \\
\hline 11 & eraldab, viiekümneks, anti, uus \\
\hline 10 & aastaks, sümboliseerida, mere, üle \\
\hline 9 & vaid, kahte, aastal, sild, lähendas, maad \\
\hline 8 & eraldas, olemasolev, viidates, \\
\hline 7 & $\begin{array}{l}\text { sellele, esialgu ( }+6 \mathrm{x} \text { ensin, } 1 \mathrm{x} \text { ensialkuun), lahe, alustas, } \\
\text { logol, selliste }\end{array}$ \\
\hline 6 & $\begin{array}{l}\text { poole, mõlema, suurte, kaks, uus, rahapada (+ rahakirstu), } \\
\text { teineteisest, neid, riik, kultuurisidemed ( }+2 \mathrm{x} \text { kulttuuri- } \\
\text { yhteydet, kulttuurivaihto, } 2 \mathrm{x} \text { kulttuurisuhde, sidokset })\end{array}$ \\
\hline 5 & $\begin{array}{l}\text { naabrit (+ kielinaapuri, naapurivaltio, naapurimaa), } \\
\text { mõlemal, uute, logo }\end{array}$ \\
\hline
\end{tabular}

* Olen lisännyt (+) taulukkoon myös sellaisen 'vapaamman' käännöksen (ja sen esiintymiskerrat), joka sopii tekstiin. Muuten oletusarvoisena käännöksenä on sanakirjasta löydettävä vastine.

Sanojen omallakin laadulla on toki vaikutusta ymmärtämiseen, mistä on todisteena se, että viron sanoja tunnistetaan ilman tekstiyhteyttä (Muikku-Werner \& Heinonen 2012). Käsittelen aluksi lyhyesti joitain viron äänteellisiä seikkoja.

Koska loppuheitto on tuttu suomessa murteittain ja puhekielessä, se ei näy estävän samankaltaisuuden havaitsemista. Loppuheitto voi yhdistyä nominatiiviin mutta myös muihin sijoihin sekä taipumattomiin sanoihin: kolm, maailmas ja lisaks. Samantapaisesti saksankielisille nomineille tyypillisen loppu-e:n puuttuminen hollannin nomineista ei haittaa saksalaisia niiden tunnistamisessa, koska vokaali painottomana ei ole kovin tärkeä. Ylipäänsä nimenomaan sananalulla on havaittu olevan keskeinen merkitys sanan merkityksen jäljittämisessä. (Möller 2007: 287, 291.) Sisäheittoiset sanat kestnud, naabrit ja viiekümneks on useimmissa tapauksissa käännetty oikein. Suomen ortografiasta poikkeavat $\ddot{u}$ 
(üks) ja õ (mõlemal), soinnilliset konsonantit (kuulub), vokaalisoinnun puute (levitamiseks), sanansisäisen $d$ :n kato (kahe ja lahe; $d$ tosin puuttuu suomenkin puhekielestä ja monista murteista) tai viron ensimmäisen tavun pitkät vokaalit suomen diftongien (keele, poole) vastineina eivät haittaa ymmärtämistä. Tekstiyhteyden merkitystä ei kuitenkaan pidä täysin unohtaa, sillä esimerkiksi irrallisten sanojen $\ddot{u}$ tuotti testatuille lukiolaisille hankaluuksia (Muikku-Werner \& Heinonen 2012: 164).

Edellä mainitut äänteelliset piirteet mainitaan usein oppikirjoissa viron erityisominaisuuksina (ks. esim. Kasik 1994: 10-16). Testattavien opiskelijoiden tiedossa ne eivät testaushetkellä olleet, joten käännösten korrektius ei perustu lingvistiseen tietoon kieltenvälisistä eroista. Kiinnostavaa on havaita, ettei niillä ole kovin kielteistä vaikutusta koherenttia tekstiä käännettäessä, mikäli viron ja suomen sanat eivät poikkea kirjoitusasultaan liikaa.

Aiemmissa tutkimuksissa valitut testisanat ovat vaihdelleet ortografisen läheisyyden tai etäisyyden perusteella. Van Bezooijen ja Gooskens käyttävät seuraavan kaltaista leksikaalisen sukulaisuuden läpinäkyvyyteen pohjautuvaa jaottelua: 1) selvästi läpinäkyvä (afrikaans uitbuiting, hollanti uitbuiting), 2) melko läpinäkyvä (afrikaans sewentig, hollanti zeventig), 3) melko läpinäkymätön (friisi jierren, hollanti jaren), 4) täysin läpinäkymätön (afrikaans hê, hollanti hebben). Oletuksena oli, että kaikentasoinen etäisyys vaikeuttaa ymmärtämistä. (Van Bezooijen \& Gooskens 2007: 256.) Myös Sild üle mere -tekstissä sukulaissanojen läpinäkyvyysaste vaihtelee, joskin useimmissa ero on melko läpinäkyvä. Taulukon 1 tuloksia katsoessa kuitenkin huomaa, ettei koherentin tekstin yhteydessä kirjoitusasun samankaltaisuus ole ainoa tae ymmärtämiselle, mikä näkyy esimerkiksi melko tai täysin läpinäkymättömien vahelisteja sellele-, lähedased-sanojen oikeiden käännösten lukuisuudesta. Sen sijaan testattaessa irrallisia sanoja ortografisen likeisyyden puutteen huomattiin vähentävän ymmärrettävyyttä ratkaisevasti (Muikku-Werner \& Heinonen 2012: 176). Jo sanan sijoittaminen epäyhtenäisen tekstin lauseeseen helpottaa merkityksen selvittämistä. Mikäli tarjolla on kotekstiä, sanan omat ominaisuudet eivät välttämättä ole keskeisimmässä roolissa. 
(Paajanen \& Muikku-Werner 2012: 250.) Tämän tutkimuksen havainnot koherentin tekstin vaikutuksesta ovat hyvin samansuuntaisia.

Myös lainasanat suomenopiskelijat tunnistavat vaivatta (samansuuntaisista havainnoista ks. Lutjeharms 2007: 276). Tosin instituut muuttuu kerran 'instituutioksi'. Partnerlus on hankalahko, koska viron johdin on erilainen kuin suomen. Koska derivaation ilmeisesti oletetaan kuuluvan myös viron ominaisuuksiin, edetään käännöksissä kantasanaa partner pidemmälle, joskin niissä etsitään ehkä vähemmän virallista ilmausta kuin 'kumppanuus' ja tarjotaan sanaa 'ystävyys'. Tekstin muista vierassanoista sümboliseerida, logo(l) ja organiseeriti sijoittuvat sellaisiin kohtiin, jotka ovat muun sanaston vuoksi jääneet kääntämättä, joten niiden todellisesta tunnistuksesta tuskin saadaan oikeaa kuvaa. Riik-sana merkityksen jäljittämisessä on osittain voinut olla apua ruotsin kielestä. Lainasanat opitaan myöhemmin kuin omakieliset, mutta ne ovat osa niin suomen kuin vironkin sanastoa eivätkä tuota lukijalle ongelmia. Kieltenväliset rajat hämärtyvät tässä suhteessa. (Möller 2007: 286; Dufva 2011: 116.)

Yhdyssanojen tunnistaminen ei välttämättä ole ongelma, jos molemmat osat ovat läpinäkyviä kuten sanoissa sugulaskeeled ja keelerühma. Soomeugri on puolestaan helppo ymmärtää paitsi muistuttavuuden vuoksi myös siksi, että se edustaa suomenopiskelijan hallitsemaa erityissanastoa, jonkinlaista ammattijargonia. Jos suurta kieltenvälistä vastaavuutta ei ole tai toinen osa ei ole sukulaissana, tunnistaminen on pulmallista. Esimerkiksi todettaessa Viron olevan kolmen tunnin laivamatkan päässä Suomesta laevasõitu-sanan jälkiosa monesti jätetään kokonaan kääntämättä ja turvaudutaan sinänsä loogiseen korvaavaan ilmaisuun 'laivalla'. Lauseke Nõukogude Liit on käännetty erittäin harvoin, vaikka maailmantiedon avulla 'Neuvostoliitto'-merkityksen voisi kuvitella hahmottuvan, varsinkin kun liit on mahdollista tunnistaa sukulaissanaksi. Osuutensa asiaan on tavallista vaativammalla tekstiympäristöllä. Testattaessa viron irrallisten yhdyssanojen ymmärtämistä on havaittu, että niiden tunnistaminen on vaikeaa. Esimerkiksi pealinn 'pääkaupunki' saa virheellisesti vastineeksi sanan 'päällinen' ja ajalugu 
'historia' suomentuu ilmaukseksi 'kello' (Muikku-Werner \& Heinonen 2012: 172, 176). Nyt käsiteltävän tekstin asiasisällön pohjalta tällaiset ehdokkaat eivät ole järkeviä, mutta aineistonikin virheelliset esimerkit tukevat havaintoa kirjoitetun tekstin yhdyssanojen hahmottamisen problemaattisuudesta.

Edellä olevat tulokset kytkeytyvät kiinnostavasti ymmärtämisen merkitystä korostaviin opetusmetodeihin. Ns. EuroCom-metodi nostaa esille 'seitsemän seulaa' (sks. die sieben Siebe); kieliä vertaillaan seitsemällä tasolla. Tekstien lukemiseen sovelletaan aiempaa ja kontekstuaalista tietoa, jotta löydettäisiin kansainväliset sanat, samalle kieliperheelle yhteiset sanat, äänteelliset vastaavuudet tai systemaattiset äänteenmuutokset, yhteiset oikeinkirjoitussäännöt ja samanlaiset ääntöasut, syntaktiset säännöllisyydet (tavalliset syntaktiset rakenteet), morfosyntaktiset säännöllisyydet sekä yhteiset prefiksit ja suffiksit (myös johtaminen ja yhdistäminen). (Klein \& Stegmann 2000; Hufeisen \& Marx 2007: 316317.) Näistä tekijöistä osan huomaa vaikuttavan myös oman aineistoni ymmärtämiseen. Informantit tuntuvat havaitsevan edellisen kaltaisia yhteyksiä viron ja suomen välillä. Näin ollen viroa ja suomeakin opetettaessa kyseisten seikkojen korostaminen on ollut ja on edelleen tärkeää.

Muutamassa tapauksessa on ounasteltavissa, että testattavat hyödyntävät äidinkielensä eri varieteetteja sisällön selvittämisessä. Esimerkiksi yhdyssanan laevasõitu alkuosa on tuttu murteellisena muotona. Muutama henkilö ymmärtää sinänsä petollisen ystävän kitsas (jonka merkitys 'saita' tosin tunnetaan paitsi suomessa myös viron murteissa) oikein 'kapeaksi' ehkä siksi, että Etelä-Savon alueella sana tunnetaan myös 'kapean' merkityksessä. Lukusanojen loppuheittoiset muodot (üks ja kaks) löytyvät suomen puhekielestä. Esialgu-sanan käännöksiin on päädyttävissä hieman vanhahtavalta kuulostavan ilmauksen 'ensi alkuun' kautta. Sanapari mõlemal kaldal (kallas 'ranta', äyräs') on käännetty 'molemmalla puolella' tai 'molemmin puolin'. On tietysti mahdoton sanoa, kuinka moni käyttää suomessa runollisen kallassanan 'reuna'-merkitystä apunaan. Yllättävästi jää kääntämättä rahvushümn, jonka ensimmäinen osa olisi yhdistettävissä sanaan rahvas (viron 
rahvus-sanallahan ei suomessa ole äännevastinetta, vrt. viron rahvas 'kansa') ja jälkiosa hymni on kansallislaulujen yhteydestä tuttu. Tähän lienee kuitenkin syynä se, ettei lausetta Isegi riikide rahvushümnide viis on ühine ole yleensä suomennettu. Kokonaisuuden jäädessä hahmottumatta yhtä sanaa ei ole käännetty, koska tehtävänannossa ei näin ole kehotettu tekemään. Joka tapauksessa lukijalla on käytettävissään muitakin resursseja kuin standardivariantti.

\subsection{Ko- ja kontekstin vaikutus ymmärtämiseen}

Jo edellisessä alaluvussa korostin sekä ko- että kontekstin merkitystä ymmärtämisessä. Tässä luvussa esittelen joitakin yksittäisiä tapauksia, joista on nähtävissä, minkälaisesta vaikutuksesta voi olla kyse.

Genetiivin päätteen katoaminen virossa (eesti keel ja Soome Kultuurikeskus) ei estä sanan funktion tunnistamista. Osasyynä on omistusmuodon todennäköisyys kotekstin perusteella: substantiivia edeltävän toisen substantiivin sija on suomen syntaksin mukaan mitä luultavimmin genetiivi, ja saman rakenteellisen tosiasian uskotaan olevan voimassa myös sukukielessä. Tosin näissä esimerkkitapauksissa pääsanankin ymmärrettävyys tukee suhteen hahmottamista.

Toisaalta on tapauksia, joissa huolimatta viron ja suomen sanojen kirjoitusasujen likeisyydestä ei oikeaa merkitystä tavoiteta. Yleensähän nimenomaan verbin kautta aktivoituu mentaalisesta sanastosta jokin toinen sana (Sağin-Şimşek \& König 2011: 322). Viidates-verbi kytkeytyy toiseen sinänsä tunnistettavaan sanaan, kultuurisuhtele, joka on ensinnäkin aika harvinainen kerasana (vrt. esim. suomessa viitaten pykälään tai asiakohtaan). Lisäksi viidates-muotoon kytkeytyvä komplementti on eri sijassa kuin suomen viitatessa-muotoon liittyvä. Tämä voi olla yksi syy siihen, että sanaliitto jää usein suomentamatta. Samankaltaisesta hankalasti kääntyvästä tapauksesta, jossa sanan rektio on eri virossa kuin suomessa, on kyse seuraavassa esimerkissä: lisaks Soomele 'Suomen lisäksi'. Hieman toisentyyppisestä suomen kielen pohjalta tehdyn oletuksen toteutumattomuudesta on lausekkeessa instituudi logol, jota 
vastaisi suomen 'instituutin logossa'. Kun natiivin suomenpuhujan morfologinen priming toteutuu itse ytimen ja sen kerailmauksen taivutusmuotona (esim. viitata + illatiivi; Jantunen \& Brunni 2012: 77), voi olla, että odotuksenmukaisen rektion puuttuminen estää kääntämisen, varsinkin niissä tapauksissa, joissa tukea ei saada muusta ympäröivästä tekstistä.

Sanaston samankaltaisuus ei siis yksinään tunnu selittävän ymmärtämistä. Aivan oikeaan merkitykseen on päädytty silloinkin, kun sanaa ei enää voi tunnistaa ulkoasun perusteella sukulaissanaksi tai sukulaisuutta ei ole. Tällöin ehkä edetään kokonaisuuksien varassa, ja outo sana prosessoidaan kotekstin perusteella. Toisen sanan uskotaan edellyttävän jonkin toisen sanan myötäesiintymistä, ja sanaa käyttäessämme otamme ehkä tiedostamattamme huomioon muun muassa sen tyypilliset kollokaatit (Hoye 2007: 8). Kiinnostava kysymys on se, onko mahdollista, että esimerkiksi suomenpuhuja siirtää äidinkielensä vierussanaodotuksen myös viroon. Esimerkiksi sana aastal tunnistetaan peräti 10 kertaa. Oikean käännöksen suurtaajuisuuteen todennäköisesti vaikuttaa sen kytkeytyminen vuosilukuun 1994, jonka etiseen asemaan ei ole tarjoutumassa suomessa kovin monta ilmeistä ehdokasta. Siten 'vuonna'- fraasin käännösvastinetta pidetään mahdollisena virossa. Jotta oletus kollokaattiodotusten 'transferista' voitaisiin todistaa oikeaksi, sen paikkansapitävyyttä olisi testattava usealla sanaliitolla siten, että muun kotekstin merkitys eliminoitaisiin mahdollisimman tehokkaasti. Joka tapauksessa lähitekstin myönteinen vaikutus onnistuneeseen lopputulokseen on havaittavissa. Kun lausekkeessa on riittävästi informaatiota, puuttuvan elementin löytäminen ei ole hankalaa. Anti-verbi tunnistettiin hyvin paitsi jonkinasteisen muistuttavuutensa myös komplementtiensa vuoksi: sellele [yhteistyölle] ja uus nimi eivät ympäristönä jätä kovin suurta valinnanvaraa, joskaan lähtökohtana ei ole verbinmuoto. Kun puhutaan virosta ja suomesta, on varsin helppo hahmottaa 'läheiset' lausekkeesta lähedased sugulaskeeled samoin kuin 'väliset' lausekkeesta kahe maa vaheliste sidemete siitä huolimatta, että viron- ja suomenkielisten sanojen kirjoitusasut ovat melko etäällä toisistaan. 
Edellä on pohdittu lähinnä viron sanojen ja niiden kotekstin yhteyksiä ymmärtämiseen. Tavoitteena oli kuitenkin punnita myös temaattisesti yhtenäisen kokonaisuuden vaikutusta viestin kääntämiseen. Seuraavassa on muutama esimerkki siitä, miten eri tavoin virkkeen merkitystä rakennetaan. Yleensä vaihtelevat sisällöt ovat loogisia, ja sopivat - ainakin testattavan mielessä - osaksi koherentin tekstin (ks. tarkemmin liite 1) sisältöä. Suomenlahden funktio tulee seuraavissa vaihtoehdoissa selväksi.

(1) Soome ja Eesti pealinnu eraldab teineteisest vaid kitsas riba Soome lahte. ["normikäännös": 'Suomen ja Viron pääkaupungit erottaa toisistaan vain kapea kaistale Suomenlahtea.']

'Suomen ja Viron pääkaupungit erottaa toisistaan vain vaivainen Suomenlahti.'

'Suomen ja Viron erottaa toisistaan vain pieni Suomen lahti.'

'Suomen ja Viron välissä on Suomenlahti'.

'Suomi ja Viro sijaitsevat eri puolilla Suomenlahtea.'

Virkkeen sanajärjestys on hankala, objektialkuisuudessaan tunnusmerkkinen. Kuten Lutjeharms (2007: 274) toteaa, sijoja käyttävissä kielissä voidaan hyödyntää ei-syntaktisia prosessireittejä lauseen temaattisen tulkinnan määrittämiseksi. Hämäävää on kuitenkin se, ettei pealinnu (monikon partitiivi) ole välttämättä tunnistettavissa objektiksi, koska suomessa erottaa-verbin yhteyteen sopisi paremmin pääkaupungit, jolloin sanaloppuisen aineksen oletusarvona olisi monikon tunnus $t$. Koska riba on tuntematon, sitä ei käännetä ja subjektiksi hahmotetaan Suomenlahti, jonka luku kongruoi yksikkömuotoisen predikaattiverbin kanssa. Se, että viron partitiivi lahte soveltuu huonosti muotonsa puolensa suomen nominatiivin paikalle, ei tunnu haittaavan. Puhetilanteiden kommunikatiivisten päämäärien saavuttamisessa virolaisen 'kvasisuomi' toimii yhtä hyvin kuin mikä muu tahansa menetelmä (Verschik 2011: 276), ja samantapaista likiarvostrategiointia tuntuu noudattavan myös viroa kääntävä. Ratkaisuja ei siis tehdä pelkästään muotojen vaan sisältöjen pohjalta. Eraldab ei ole aivan lähellä suomen erottaa-sanaa, mutta tekstiyhteys auttaa ydinsanoman tajuamista. Kaiken kaikkiaan tyypillistä 
on pelkistäminen: hankalat sanat jätetään pois, mutta tekstin pääajatus välittyy silti.

Sen sijaan vähemmän konkreettisen kaarisillan merkitys jää osalle informanteista hämäräksi:

(2) Soome Instituudi direktor Juhani Salokannel kasutab sellele kultuurisuhtele viidates tihti väljendit "kaarsild".

["normikäännös": 'Juhani Salokannel, Suomen-instituutin johtaja, käyttää usein ilmausta "kaarisilta" viitatessaan tähän kulttuurisuhteeseen.']

'Suomi-instituutin johtaja J.S. puhuu sellaisiin kulttuuri-suhteisiin viitatessaan kaarisillasta.

'Suomi instituutin johtaja Juhani Salokannel kuvaa Suomen ja Viron kulttuurien välistä suhdetta "kaarisilta"-termillä.'

'Suomi-instituutin johtajan Juhani Salokantelen mielestä tällainen kulttuurivaihto toimi maidenvälisenä "siltana".

Vaikka useimmat testattavat eivät ymmärrä sanoja kasutab, tihti ja väljendit, sukulais- tai lainasanojen perusteella rakentuu mielekäs asiakokonaisuus. Kun viidates-verbin ja sen komplementin välinen suhde tuntuu aiheuttavan edellä käsiteltyjä (ks. 223) ongelmia, oikaistaan ja poimitaan vain ydin, kulttuurisuhteiden rinnastuminen kaarisiltaan. Lukijat saattavat tyytyä ymmärtämisessään varsin vähään: vastaanotettu tieto on epätarkempaa kuin lähetetty (Lutjeharms 2007: 276).

Seuraava esimerkki on kiinnostava, sillä huolimatta kaikkien sanojen tunnistettavuudesta läheskään kaikki eivät päädy samaan asiasisältöön:

(3) [sateenkaaren] Mõlemal pool on rahapada.

[“normikäännös": 'Molemmissa päissä on rahapata (= kultaruukku).']

'Molemmilla puolilla on rahapata'

'Ja molemmissa päissä siltaa on rahakirstu.'

'Molemmilla puolilla on rahavaroja.'

'Rahoitus tulisi molemmilta puolilta.'

Kun virkkeen alkuosan viittauskohde vikerkaar 'sateenkaari' jää useimmilta ymmärtämättä, rahapadan kytkentä tekstiin tuottaa ongelmia. 
Vaikka kansainvälinen uskomus sateenkaaren molemmista päistä löytyvästä aarteesta on hyvinkin tuttu, aikaisemmin tekstissä esiintyvä kaarisilta-metafora ei assosioidu rahalöydöksiin. Selvästi on ymmärretty kulttuurisuhteiden kaksisuuntaisuus, joten rahapata yhdistetään luontevasti molemmilta osapuolilta tarvittavaan rahoitukseen, vaikka alkuperäisessä tekstissä puhutaan vain logossa olevan kuvien vaihtoehtoisista tulkinnoista. Teksti rakennetaan koherentiksi kokonaisuudeksi, jossa osat loksahtavat paikalleen.

Leksikaalinen samanlaisuus syrjäytyy ajoittain tunnistamisen primaarina perusteena. Jos lukija tavoittelee ensisijaisesti koherenttiutta ja kokonaisuuteen epäsopiva tieto esimerkiksi hylätään tai mukautetaan luotuun mielikuvaan, yksikin väärinymmärrys voi johtaa useampiin 'virheisiin' (Lutjeharms 2007: 276). Myös tekstielementteihin kytkeytyvien erilaisten rakenteellisten olettamusten täyttymättömyys, esimerkiksi outo rektio, voi haitata merkitysten tavoittamista.

\section{Informanttien näkemyksiä ymmärtämisestä}

Tässä yhteydessä keskityn niihin kommentteihin, jotka kytkeytyvät nimenomaan käännösten onnistumisen edellytysten arviointiin (aiemmista informanttien näkemyksistä ks. Kaivapalu \& Muikku-Werner 2010). Odotuksenmukaisesti sanahahmon samankaltaisuus kirjataan useissa vastauksissa ymmärtämisen edellytykseksi. Tällainen kieltenvälisten ekvivalenssien rakentamisen taito on tärkeää reseptiivisessä monikielisyydessä, vaikka siinä piileekin vaara yliyleistyksiin (Verschik 2011: 273).

Kuten edellisessä luvussa osoitettiin, loppuheitto tai vokaalisointu eivät tuota ongelmia, mikä on nähtävissä kommenteistakin. Esimerkin (4) perusteella voi olettaa, että suomen opiskelijaa auttaa hänen tietonsa kielen ilmiöistä; epäselväksi tosin jää, perustuuko hänen kannanottonsa viron ominaisuuksista hänen käännettävästä tekstistä tekemiinsä havaintoihin vai onko hän oppinut vokaalisoinnun puutteen ja sisä- ja loppuheiton runsauden jollain kurssilla. Myös viron 
soinnittomien lenisklusiilien merkkeinä käytettyjen $b: n, d: n$ ja g:n ja suomen $p: \mathrm{n}, t: \mathrm{n}$ ja $k: \mathrm{n}$ vastaavuus on ollut helppo havaita samoin kuin ensitavun pitkien vokaalien yhteys diftongeihin. Sananalun tärkeys ilmenee esimerkistä (6).

(4) Jotkut sanat ovat samanlaisia kuin suomessa. Vaikka virossa ei ole vokaalisointua, oli helppo ymmärtää niitä sanoja, joissa "pitäisi” olla vokaalisointua. Sisäheitto oli joskus ongelmallinen, mutta loppuheitto ei ollut.

(5) Virossa esiintyy "b"kin ja ajattelin että suomen vastaava sana sisältäisi "p":tä. Yritin tehdä pitkistä vokaaleista diftongeja ja arvata onko sanoissa astevaihtelua.

(6) Hankala sana oli esimerkiksi "peaaegu", siis liian paljon vokaalia tässä sanassa.

Viron ja suomen leksikaalinen samankaltaisuus on se alue, josta testattavat tietävät jotain. Myös morfologiasta ja syntaksista havaitaan yhteisiä piirteitä. Suomen kielen opiskelijoilla on tietysti tavallista paremmat edellytykset tunnistaa muotoja ja rakenteita, mistä voi olla apua ymmärtämisessä. Suomesta tuttujen asioiden havaitseminen virosta ei kuitenkaan välttämättä onnistu (9):

(7) Vaikka jotain sanaa ei entuudestaan tuntenut, pystyi sen sanaluokan ja syntaktisen roolin yleensä päättelemään.

(8) Verbit, adjektiivit ja substantiivit oli suht helppo erottaa tekstistä ja toisistaan.

(9) Oli hankala miettiä, mitkä ainekset kuuluivat itse sanaan ja mitkä olivat taivutussuffikseja.

Aiemmat tutkimukset ovat osoittaneet, että jos sukulaissanat puuttuvat tai niitä on vähän, ymmärrettävyys kärsii. Jopa yhden keskeisen sanan merkityksen uupuminen saattaa tehdä virkkeestä käsittämättömän (van Beezoijen \& Gooskens 2007: 258). Testattavat pitivät tietokatkon synnyn syynä nimenomaan useampien sanojen merkityksen jäljittämättömyyttä. Tällöin tilannetta ei pelasta edes tekstiyhteys: 
(10) Vaikka kontekstista onkin tukea yksittäisten sanojen merkityksen selvittämisessä, vieraiden elementtien kasaumat estävät ymmärtämisen.

(11) Ymmärtäminen vaikeutui eniten, kun samassa lauseessa oli useampi vieras sana peräkkäin ja näin lauseen sisältöä oli vaikea hahmottaa edes asiayhteyden perusteella.

Tavallisimmin kontekstistä on kuitenkin hyötyä. Sen tärkeys on kirjattu hyvin moneen kommenttiin.

(12) Jos en ymmärtänyt, katsoin mitä lähistöllä luki.

(13) Lisäksi tarkkailin sanoja, jotka toistuivat useassa kohdassa.

(14) Kontekstista päättelemällä, lausumalla sanat esim. mielessäni ääneen.

Kiinnostavia ovat myös ne havainnot, jotka tuovat esille testattavien käyttämien kielellisten resurssien runsauden. Lähtökohtana ei ole pelkästään standardisuomi, vaan tunnistamisen pohjana on erilaisia kielimuotoja ja vieraita kieliä (ks. aiemmin s. 221 ja 222):

(15) Yritin miettiä, olisiko esim. sanassa mitään tuttua, muistuttaisiko se suomea tai muuta kieltä.

(16) Jotkin viron sanat tuntuvat olevan lähellä suomen kielen murre- tai slangisanastoa (informatsiooni), mikä helpottaa ymmärtämistä.

(17) Monet sanat muistuttavat myös hieman vanhahtavia suomen kielen sanoja kuten "esialgu” vrt. "ensi alkuun".

Testattavat ovat huomanneet yleisen lingvistisen tietämyksen merkityksen; tosin heidän esittämänsä selitykset eivät välttämättä osu oikeaan: informatsiooni ei ole murretta eikä slangia. Opiskelun tuoma asiantuntemus on kuitenkin avuksi esimerkiksi kielisukulaisuutta käsittelevän jakson ymmärtämisessä. Historiallisista tapahtumista kertovan osion selvittämiseen on taas hyötyä yleistiedosta.

(18) Varmasti suomen kielen opiskeluilla on merkitystä ymmärtämiselle ja ylipäätään sillä, että tietää suomen ja eestin kielen olevan sukulaiskieliä.

(19) Kokonaiskuva oli helppo ymmärtää historiantietojen ja yhteisten sanojen avulla päättelemällä, vaikka saattoi mennä pieleenkin.

(20) Kohtia jotka tajusi yleistiedon perusteella. 
Edellisten kommenttien pohjalta on nähtävissä, että pelkkä erojen tai samanlaisuuksien korostaminen on liian 'yksikielistä: lähtökohtana olisi yksi suomen tai viron kielimuoto. Testatut näkevät kielen vaihtelevana yksikkönä ja hyödyntävät kaikkea kieleen liittyvää tietoaan, kuten suomen varieteettien tuntemustaan sekä käsityksiään kontakteista ja niiden tuomista lainasanoista. (Ks. myös Dufva ym. 2011: 116, 119.) Erityisesti reseptiivisessä monikielisyydessä tarvitaan runsaasti erilaisia resursseja (Lüdi 2006: 173-174). Tekstiin tutustuvilla onkin käytössään erilaisia sekä lingvistiä että tekstinulkoiseen maailmantietoon perustuvia, yhtäaikaisesti aktivoituneita kompetensseja. Yleensä testattavien vastaukset ovat varsin samansuuntaisia kuin aiemmissakin sukukielen ymmärtämistä käsittelevissä kyselyissä. Esimerkiksi lainaamisen mahdollisuus on mainittu jo irrallisten sanojen yhteydessä (Muikku-Werner \& Heinonen 2012: 174) ja muun muassa päättelykyky lauseisiin sijoitettujen sanojen yhteydessä (Paajanen \& Muikku-Werner 2012: 240). Arvaamista tai mielikuvitusta informanttini eivät mainitse, mikä todistanee tekstin koherenttiuden vaikutuksesta.

\section{Tuloksista}

Edellä esitetyt tulokset osoittavat, että ymmärtämistä helpottaa ennen kaikkea kielisukulaisuus, jonka ilmentymiä löydetään niin sanaston kuin rakenteidenkin tasolta. Tämän artikkelin fokus on ensisijaisesti leksikossa. Samankaltaisuutta etsittäessä arjen havainnot äidinkielen moninaisuudesta helpottavat viron sanan tunnistamista: kaikki suomen varieteetit ovat avuksi. Samantapaisia strategioita käyttävät irrallistenkin sanojen tunnistajat, mutta ilman mielekästä tekstiyhteyttä jopa tuttu sanahahmo jää tavoittamatta ja yhdyssanasta tulee yhdistämätön (vihmavari 'sateenvarjo' tulkitaan *ämpäriksi'; Muikku-Werner \& Heinonen 2012: 178). ${ }^{2}$ Yhtenäisen tekstin sisällön välittymistä selittäviä

\footnotetext{
2 Kaiken kaikkiaan koherentin tekstin sanoja tunnistettiin enemmän ja johdonmukaisemmin kuin sanoja ilman kontekstia tai irrallisissa lauseissa (Muikku-Werner \& Heinonen 2012; Paajanen \& Muikku-Werner 2012).
} 
tekijöitä ovat ennen kaikkea ko- ja konteksti sekä lingvistinen ja maailmantieto. Siten myös tekstien yhteydessä voidaan puhua LaRa-tilanteesta (ks. 212): monien aktivoituneiden kompetenssien muodostama kokonaisuus edistää ymmärtämiseen johtavaa päättelyä.

Aina teksti ei silti avaudu. Toisaalta amatöörikääntäjille tuntuu riittävän keskeisen teeman selville saaminen. Semanttiset likiarvot ovat kuitenkin yleensä saman 'kentän' jäseniä, joten käsiteltävänä on sentään yksi ja sama, kokonaistekstiin kytkeytyvä seikka. Sen sijaan irrallisiin lauseisiin sijoittuvien sanojen käännöksistä Paajanen on havainnut, että ne saattavat käsitellä aivan muuta asiaa kuin alkuperäinen virke: Selle viisi on loonud Pacius *'Kello viisi on lounas' ["normikäännös": 'Tämän sävelmän on luonut Pacius.'] (Paajanen 2012: 26). Joskus koherentin kokonaisuuden tavoitteleminen Sild üle mere -tekstistä johtaa loogiseen mutta virheelliseen tulokseen. Tällöin hahmotettuun yleiskuvaan sopimaton aines jätetään pois, vaikka kyse olisi samankaltaisuuden avulla helposti tunnistettavasta sanasta. Tosin poistoja lisää myös testitilanteen laatu: aikaa oli käytettävissä melko vähän.

Tämänsuuntaiset tutkimustulokset eivät toki ole kaikilta osin uusia (Kaivapalu \& Muikku-Werner 2010). Tällä kertaa pystytään kuitenkin osoittamaan, etteivät esimerkiksi tietyt viron ja suomen väliset äänteelliset erot ole este ymmärtämiselle. Myös vierussanojen (kollokaattien) keskinäisen suhteen tärkeys korostuu. On mahdollista, että suomen pohjalta tunnistamattomissa oleva sana ymmärretään niiden odotusten pohjalta, joita todennäköisestä kerasanasta on lähtökielessä. Toisaalta muoto voi olla hyvinkin ratkaiseva: viron erilainen rektio voi aiheuttaa sen, ettei sukulaissanaakaan kelpuuteta käännösvastineeksi vaan syntaktisesta yhteensopimattomuudesta tulee ymmärtämisen este.

Tulokset osoittavat sen, ettei reseptiivinen tieto ole passiivista. Hufeisenin ja Marxin (2007: 308) tavoin on todettava, että monikielisyys on vaativa kognitiivinen ja lingvistinen tehtävä, johon on kouluttauduttava. Huomiota voisi kiinnittää eri kompetenssien aktivoimiseen. Epämuodollisen tutustumisen viroon ei tarvitse olla sääntölähtöistä, eikä tarkasteltavana kohteena ole pelkästään viro vaan myös 
ne kielet, jotka ovat olleet kosketuksissa viron kanssa ja jättäneet siihen jälkensä.

Lähtökieleksikin on hahmotettavissa erilaisten varieteettien muodostama kokonaisuus, ei vain standardisuomi. Näkemys on hyvin samantapainen kuin uuden kielen oppimisesta puhuttaessa: korostetaan todellisten ilmenemismuotojen sekä erilaisten genrejen ymmärtämisen ja käytön tärkeyttä. (Dufva ym. 2011: 111-112, 117.) Vaikka kielitieteen perusteita hallitsevat informantit osasivat hyödyntää edellä mainittuja seikkoja ja toiminnallisia ratkaisuja, tällaisia taitoja ei kaikilla automaattisesti ole. Niistä olisi monikieliseen viestintään pyrittäessä hyvä mainita, sillä on havaittu, että kieltenvälisten tunnistus- yms. strategioiden harjoittaminen auttaa (Hufeisen \& Marx 2007: 315-316).

Koska testityypilläkin todistettavasti on vaikutusta tuloksiin, on syytä kokeilla myös muita menetelmiä kuin kääntämistä tai sisällön selittämistä. Valitettavasti yksilönvälisten erojen kontrollointi on metodista riippumatta lähes mahdotonta. Tässä artikkelissa esitellyn käännöstehtävän yhteydessä lisäongelmia aiheuttivat taustatiedon vaihtelevat määrät ja vastaajien erilaiset käsitykset hyvästä käännöksestä. Miten kääntämiseen pitäisi ohjeistaa? Väljä instruktio johtaa siihen, että käännöksissä tavoitellaan kokonaisuuksia. Tutkijan kannalta pitkät kääntämättä jääneet jaksot ovat jossain määrin harmillisia, kun ei käy selväksi, miten paljon niissä on ollut sanoja, joiden merkitys on tajuttu mutta jotka on jätetty kääntämättä, koska kokonaisuus ei ole hahmottunut. Toisaalta jos informantteja kehotettaisiin suomentamaan teksti sanasta sanaan, he voisivat turhautua “osaamattomuudestaan”. Käytännön sovellusten kannalta ja reseptiivisen monikielisyyden toteutumiseksi sukukieleen tutustujaa tulisi tietysti opettaa sietämään ymmärtämis- ja tietoaukkoja eikä suremaan tunnistamattomia sanoja. 


\section{Kiitokset}

Kiitän nimettömiä arvioijia tämän artikkelin viimeistelyn kannalta erittäin hyödyllisistä kommenteista ja kollegaani Hannu Remestä korvaamattomasta avusta.

\section{Lähteet}

Alvre, Paul, Raul Vodja 1995. Pulma poikineen. Virolais-suomalainen vertailusanakirja. Helsinki: WSOY.

Braunmüller, Kurt 2007. Receptive multilingualism in Northern Europe in the Middle Ages. A description of a scenario. - Jan D. ten Thije, Ludger Zeevaert (Eds.). Receptive Multilingualism. Linguistic Analyses, Language Policies and Dialectic Concepts. Amsterdam: John Benjamins, 25-47.

Delsing, Lars-Olof 2007. Scandinavian intercomprehension today. - Jan D. ten Thije, Ludger Zeevaert (Eds.). Receptive Multilingualism. Linguistic Analyses, Language Policies and Dialectic Concepts. Amsterdam: John Benjamins, 231-246.

Doetjes, Gerke 2007. Understanding differences in inter-Scandinavian language understanding. - Jan D. ten Thije, Ludger Zeevaert (Eds.). Receptive Multilingualism. Linguistic Analyses, Language Policies and Dialectic Concepts. Amsterdam: John Benjamins, 217-230.

Dufva, Hannele, Minna Suni, Mari Aro, Olli-Pekka Salo 2011. Languages as objects of learning: Language learning as a case of Multilingualism. - Apples - Journal of Applied Language Studies 5 (1), 109-124.

Hoey, Michael 2007. Lexical priming and literary creativity. - Michael Hoey, Michaela Mahlberg, Michael Stubbs, Wolfgang Teubert (Eds.). Text, Discourse and Corpora. Theory and Analysis. London: Continuum, 7-29

Hufeisen, Britta, Nicole Marx 2007. How can DaFnE and EuroComGerm contribute to the concept of receptive multilingualim. - Jan D. ten Thije, Ludger Zeevaert (Eds.). Receptive Multilingualism. Linguistic Analyses, Language Policies and Dialectic Concepts. Amsterdam: John Benjamins, 307-321.

Jantunen, Jarmo, Sisko Brunni 2012. Morfologinen priming ja fraseologia vieraan kielen oppimisessa: korpustutkimus oppijansuomesta. - Lähivõrdlusi. Lähivertailuja 22, 71-100. http://dx.doi.org/10.5128/LV22.03

Kaivapalu, Annekatrin 2007. Äidinkieli vieraiden kielten opiskelussa - etu vai haitta? - Olli-Pekka Salo, Tarja Nikula, Paula Kalaja (Toim.). Kieli 
oppimisessa - Language in Learning. AFinLA:n vuosikirja 65. Jyväskylä: AFinLA, 289-309.

Kaivapalu, Annekatrin 2009. Vironkielisen suomenoppijan äidinkieli - ongelma, haaste vai voimavara? - Virittäjä 3, 382-402.

Kaivapalu, Annekatrin, Pirkko Muikku-Werner 2010. Reseptiivinen monikielisyys: miten suomenkielinen oppija ymmärtää viroa äidinkielensä pohjalta? - Lähivõrdlusi. Lähivertailuja 20, 68-97. http://dx.doi.org/10.5128/ $\underline{\text { LV} 20.03}$

Kasik, Reet 1994. Hakkame rääkima! Viron kielen peruskurssi. Turun yliopiston suomalaisen ja yleisen kielitieteen laitoksen julkaisuja 37. Turku: Turun yliopisto.

Kuldsepp, Toivo, Tõnu Seilenthal 1980. Mõnda Eestist. Viron kielen alkeiskurssi. Helsinki: Suomalaisen Kirjallisuuden Seura.

Klein, Horst G., Tilbert D. Stegmann 2000. EuroComRom - Die sieben Siebe: Romanische Sprachen sofort lesen können. Aachen: Shaker Verlag.

Lutjeharms, Madeline 2007. Processing levels in foreign-language reading. - Jan D. ten Thije, Ludger Zeevaert (Eds.). Receptive Multilingualism. Linguistic Analyses, Language Policies and Dialectic Concepts. Amsterdam: John Benjamins, 267-284.

Lüdi, Georges 2006. Multilingual repertoires and the consequences for linguistic theory. - Kristin Bührig, Jan D. ten Thije (Eds.). Beyond Misunderstanding. Linguistic Analyses of Intercultural Communication. Amsterdam: John Benjamins, 11-42.

Muikku-Werner, Pirkko, Maria Heinonen 2012. Lumesadu - 'tarina' vai 'lumikasa' vai ei kumpikaan? Suomalaiset lukiolaiset viron sanoja tunnistamassa. Lähivõrdlusi. Lähivertailuja 22, 157-187. http://dx.doi.org/10.5128/ $\underline{\text { LV22.06 }}$

Möller, Robert 2007. A computer-based exploration of the lexical possibilities of intercomprehension. Finding German cognates of Dutch words. - Jan D. ten Thije, Ludger Zeevaert (Eds.). Receptive Multilingualism. Linguistic Analyses, Language Policies and Dialectic Concepts. Amsterdam: John Benjamins, 283-305.

Paajanen, Ilona 2012. Kitsas tee - 'laiha tee' vai 'kapea tie'? Suomen kielen opiskelijat ja viron ymmärtäminen testissä. Julkaisematon pro gradu -tutkielma. Itä-Suomen yliopisto.

Paajanen, Ilona, Pirkko Muikku-Werner 2012. Tee on kitsas - onko 'tee kitkerää' vai oletteko 'te saita'? Suomalaiset opiskelijat viroa ymmärtämässä. - Lähivõrdlusi. Lähivertailuja 22, 219-258. http://dx.doi.org/10.5128/LV22.08 
Pajusalu, Renate, Merja Hietaharju,Viive Taro, Kai Yallop 1999. Keelesild. Viron kielen oppikirja. Helsinki: Otava

Rehbein, Jochen 2006. The cultural apparatus: thoughts on the relationship between language, culture, and society. - Kristin Bührig, Jan D. ten Thije (Eds.). Beyond Misunderstanding. Linguistic Analyses of Intercultural Communication. Amsterdam: John Benjamins, 43-96.

Rehbein, Jochen, Jan D. ten Thije, Anna Verschik 2011. Lingua receptiva (LaRa) - remarks on the quintessence of receptive multilingualism. International Journal of Bilingualism 16 (3), 248-264. http://dx.doi. org/10.1177/1367006911426466

Ringbom, Håkan 1987. The Role of the First Language in Foreign Language Learning. Clevedon: Multilingual Matters.

Ringbom, Håkan 2007. Cross-linguistic Similarity in Foreign Language Learning. Clevedon: Multilingual Matters.

Sağin-Şimşek, Çiğdem, Wolf König 2011. Receptive multilingualism and language understanding: intelligibility of Azerbaijani to Turkish speakers. - International Journal of Bilingualism 16 (3), 315-331. http://dx.doi. org/10.1177/1367006911426449

Singer, Murray 2007. Inference processing in discourse comprehension. - M. Gareth Gaskell (Ed.). The Oxford Handbook of Psycholinguistics. Oxford: University Press, 343-359.

van Bezooijen, Renée, Charlotte Gooskens 2007. Interlingual text comprehension. Linguistic and extralinguistic determinants. - Jan D. ten Thije, Ludger Zeevaert (Eds.). Receptive Multilingualism. Linguistic Analyses, Language Policies and Dialectic Concepts. Amsterdam: John Benjamins, 249-263.

Verschik, Anna 2011. Practising receptive multilingualism: Estonian-Finnish communication in Tallinn. - International Journal of Bilingualism 16 (3), 265-286. http://dx.doi.org/10.1177/1367006911426465

Zeevaert, Ludger, Jan D. ten Thije 2007. Introduction. - Jan D. ten Thije, Ludger Zeevaert (Eds.). Receptive Multilingualism. Linguistic Analyses, Language Policies and Dialectic Concepts. Amsterdam: John Benjamins, 1-21.

\section{Pirkko Muikku-Werner}

Itä-Suomen yliopisto, humanistinen osasto, suomen kieli ja kulttuuritieteet

PL 111

Fl80101 Joensuu, Finland

pirkko.muikku-werner@uef.fi 


\section{Liite 1}

\section{Sild üle mere}

\section{Terttu Nurro}

Soome Instituut asutati Eestis aastal 1994 kahe maa vaheliste kultuuri- ja hariduskoostöö arendamiseks, informatsiooni levitamiseks Soome kohta ning Soome ja Eesti vaheliste sidemete tugevdamiseks kõigis ühiskondliku ja majanduselu valdkondades.

Soome ja Eesti pealinnu eraldab teineteisest vaid kitsas riba Soome lahte: vahemaad on vaevalt 80 kilomeetrit ja kolm tundi laevasõitu. Soome ja eesti keel on lähedased sugulaskeeled. Lisaks Soomele ja Eestile on maailmas vaid üks riik, mille riigikeel kuulub soomeugri keelerühma: Ungari. Selliste omavahel suguluses olevate väikeste keelte puhul, nagu seda on soome ja eesti keel, on lähedane kultuurialane partnerlus loomulikult oluline mõlema poole jaoks. Soome Instituudi direktor Juhani Salokannel kasutab sellele kultuurisuhtele viidates tihti väljendit 'kaarsild'. Muide, kaarsilda on kasutatud ka instituudi logol, kuigi logo pilt võiks sümboliseerida ka vikerkaart - mõlemal pool on rahapada.

Kultuurisidemed Soome ja Eesti vahel on kestnud juba pikka aega. Ajalugu on neid kahte suurte riikide naabrit karmilt kohelnud ja rahvuslik ärkamine, mis toimus mõlemal maal 19. ja 20. sajandi vahetusel, lähendas neid kahte maad. Isegi riikide rahvushümnide viis on ühine. Kuid Teine maailmasõda eraldas need kaks riiki teineteisest: Eestist sai üks Nõukogude liiduvabariikidest ja see raskendas vaba suhtlemist peaaegu viiekümneks aastaks. Nõukogude Liidu nõrgenemisele ja viimaks ka kokkuvarisemisele järgnes Eestis uus ärkamisaeg ja pärast seda iseseisvuse väljakuulutamine 1991. aastal. Soov vanad partnerlussuhted taastada oli suur Soome lahe mõlemal kaldal ja Tallinnas avatigi peagi väike Soome Kultuurikeskus. See toimis esialgu Soome Tuglase Seltsi, Eesti sõprade ühingu osakonnana, hiljem arenes see praeguseks Soome Instituudiks. Instituut asutati aastal 1993.

Kui Soome Instituut viimaks 1994. aasta alguses tööd alustas, oli tegu pigem omamoodi taasühinemise, mitte uute suhete loomisega. Juba olemasolev koostöö lihtsalt organiseeriti ümber ja sellele anti uus nimi. 


\title{
Understanding Estonian texts on a Finnish language base
}

\author{
PIRKKO MUIKKU-WERNER \\ University of Eastern Finland
}

The impact of the similarity of source and target language on the learning process has been the subject of many studies. However, more information is needed about how cross-linguistic parallels are used when there is no formal instruction involved. For example, in casual discussions where each participant uses their own language, common elements are often recognized and communication proceeds in a reasonably unproblematic way. Receptive multilingualism of this kind is also connected with texts: we know that cognates facilitate reading comprehension.

The aim of this article is to find out which words Finnish readers understand, and whether similarity is the main reason for recognition or whether there are other explanations. The informants were given a text in Estonian, and they were asked to translate it. They were also asked to describe their own impressions of what had helped them understand the text. The informants were Finnish language students without previous Estonian skills. As expected it was easy to trace the meaning of those cognates which were almost identical or whose relatedness was more or less transparent. Equivalents were sought with the help of modern standard Finnish, archaic vocabulary or common loan words. However, similarity is no guarantee for comprehension if the co-text does not support the perception of familiarity. Interestingly, in order to construct a coherent - not necessarily correct - whole, the translator can give up even an obvious cognate relationship, leaving a word out or translating it incorrectly. When evaluating the results one has to remember that "lay translators" have different strategies: one proceeds word by word, the other by building consistent texts.

Keywords: cognate language; receptive multilingualism; similarity; translation test 